Inventa : Jurnal Pendidikan Guru Sekolah Dasar

http://jurnal.unipasby.ac.id/index.php/jurnal_inventa

\title{
PROBLEM BASED LEARNING UNTUK MENINGKATKAN KEAKTIFAN DAN MOTIVASI BELAJAR PESERTA DIDIK KELAS II DI SDN DUKUH MENANGGAL I
}

\author{
Ummayasri \\ SDN Dukuh Menanggal I Surabaya \\ Corresponding author E-mail: ummayasri.spd@gmail.com
}

Kata Kunci :
Keaktifan belajar,
motivasi, problem based
learning

learning

\begin{abstract}
Keaktifan peserta didik dan motivasi belajar peserta didik kelas II masih rendah sehingga dirasa perlu implementasi model Problem Based Learning untuk meningkatkannya. Penelitian ini bertujuan untuk meningkatkan keaktifan dan motivasi belajar peserta didik pada pembelajaran tema 9 melalui model Problem Based Learning di kelas II Semester 2 SDN Dukuh Menanggal I. Penelitian ini merupakan penelitian tindakan kelas yang dilaksanakan dengan tiga siklus terdiri dari dua kali pertemuan tiap siklus. Teknik pengumpulan data pada penelitian peserta didik, angket dan lembar observasi. Hasil penelitian setelah dilakukan tindakan menggunakan model model Problem Based Learning pada siklus I menunjukkan peningkatan sebesar 57. Pada siklus II mengalami peningkatan dengan perolehan nilai rata-rata keaktifan peserta didik mencapai 71 dan Siklus 3 mengalami peningkatan yang cukup signifikan dilihat dari hasil rata-rata yang di dapatkan mencapai 84 Motivasi belajar peserta didik pada siklus 1 didapatkan ratarata nilai keaktifan peserta didik mencapai 53.Tahap siklus 2 hasil rata-rata nilai motivasi belajar peserta didik mencapai 70. Mengalami peningkatan pada siklus 3 yang cukup signifikan dilihat dari hasil rata-rata yang di dapatkan mencapai 86 . Disimpulkan bahwa model Problem Based Learning dapat meningkatkan keaktifan dan motivasi belajar peserta didik pada pembelajaran tema 9 kelas kelas II Semester 2 SDN Dukuh Menanggal I.
\end{abstract}

Keyword :

Active learning, motivation, problem based learning
Student activity and learning motivation of class II students are still low, so it is necessary to implement a Problem Based Learning model to improve it. This study aims to increase student activity and motivation in learning theme 9 through the Problem Based Learning model in class II Semester 2 SDN Dukuh Menanggal I. This research is a classroom action research conducted in three cycles consisting of two meetings each cycle. Data collection techniques on student research, questionnaires and observation sheets. The results of the study after using the Problem Based Learning model in the first cycle showed an increase of 57. In the second cycle there was an increase with the acquisition of the average value of student activity reaching 71 and Cycle 3 experiencing a significant increase seen from the average results obtained. get reached 84 students' learning motivation in cycle 1 obtained the average value of student activity reached 53. Cycle 2 the average value of student learning motivation reached 70 . There was an increase in cycle 3 which was quite significant seen from the average results obtained reached 86. It was concluded that the Problem Based Learning model could increase students' activeness and motivation in learning the theme of 9th grade class II Semester 2 SDN Dukuh Menanggal I. 


\section{Pendahuluan}

Pendidikan merupakan hak yang dimiliki oleh setiap manusia tidak memandang itu dari umur, gender, ras, dan agama. Pendidikan merupakan kewajiban yang harus dijalani oleh setiap warga Indonesia. Melihat dari Sumber Daya Alam di Indonesia, alam di Indonesia mempunyai kekayaan yang melimpah. Sangat disayangkan apabila sumber daya manusia tidak bisa memanfaatkan kekayaan alam yang ada di Indonesia. Oleh karena itu, peningkatan mutu dan karakter pada pendidikan saat ini merupakan salah satu hal penting.

$$
\text { Pengembangan kurikulum }
$$

2013 merupakan bagian dari strategi meningkatkan capaian pendidikan (Fanny, 2019). Disamping kurikulum, terdapat sejumlah faktor diantaranya lama peserta didik bersekolah, lama peserta didik tinggal disekolah, pembelajaran peserta didik aktif berbasis kompetensi, buku pegangan dan guru sebagai ujung tombok pelaksana pendidikan. Maka dari itu, peran guru dalam mengoptimalkan tematik sangatlah penting. Guru diharapkan mampu mengaitkan mata pelajaran satu dengan mata pelajaran yang lain dalam satu tema tertentu (Sari dan Sulistyawati, 2021). Berhasil tidaknya proses pembelajaran disuatu sekolah di pengaruhi oleh banyak faktor, salah satu faktor tersebut adalah penggunaan media pembelajaran yang menarik dan sesuai dengan tema pada pembelajaran. Sehingga guru harus mampu berinteraksi serta merancang proses pembelajaran yang tepat dan menyenangkan. Peneliti melakukan observasi di kelas IISDN Dukuh Menanggal I. Permasalahan dari hasil observasi keaktifan dan motivasi peserta didik dalam pembelajaran masih rendah. Hasil penilaian afektif dan psikomotor peserta didik pada tema 8 masih ada yang nilainya belum mencapai KKM. Peserta didik kurang antusias saat proses pembelajaran. Fasilitas pendukung seperti media pembelajaran kurang dimanfaatkan guru. Selain itu, peserta didik kurang menunjukan minat dan antusiasnya dalam proses belajar. Dalam proses pembelajaran, beberapa peserta didik tidak memperhatikan pelajaran yang diberikan oleh guru dan tidak serius mengikuti pelajaran terlihat saat proses diskusi beberapa peserta didik tidak merespon saat diberikan pertanyaan dan diminta mengajukan pertanyaan.

Hal ini disebabkan karena minat dan motivasi peserta didik untuk mengikuti kegiatan pembelajaran daring masih rendah sehingga berdampak juga terhadap hasil belajar peserta didik. Oleh karena itu, diperlukannya metode pembelajaran efektif,kreatif, dan inovatif agar dapat mengembangkan suasana belajar mengajar pada google meet yang optimal. Salah satu cara yang dapat digunakan untuk mengurangi kesulitan peserta didik dalam proses belajar yaitu menggunakan model pembelajaran Problem Based Learning. Upaya pencapaian 
kondisi dengan penggunaan model pembelajaran yang dapat membuat peserta didik dapat aktif mengeluarkan pendapatnya dan menemukan konsep sendiri yaitu menggunakan model pembelajaran Problem Based Learning (pembelajaran penemuan). Menurut Amir (2018), menyatakan bahwa pembelajaran berbasis masalah merupakan pembelajaran yang terjadi sebagai hasil kegiatan peserta didik dalam memanipulasi, membuat struktur, dan menstranformasikan informasi baru. Dalam belajar penemuan, peserta didik dapat membuat perkiraan (conjucture), merumuskan suatu hipotesis dan menemukan kebeneran dengan menggunakan proses induktif atau proses deduktif, melakukan observasi dan membuat ekstrapolasi.

Penggunaan model Problem Based Learning mengubah suatu proses pembelajaran yang bersifat fokus ke guru beralih ke situasi pembelajaran yang berpusat pada peserta didik (Jamal, dkk, 2019). Model Problem Based Learning merupakan suatu model pembelajaran yang menjadikan peserta didik aktif dalam menemukan, memecahkan suatu permasalahan melalui bimbingan dari guru, peserta didik akan diarahkan mencari suatu informasi, mengolah, dan membahasnya pada pembelajaran (Mann, dkk, 2021). Dalam proses belajar mengajar diperlukan adanya motivasi belajar sebagai penggerak bagi peserta didik untuk merasa senang dan mau dalam belajar.

Menurut Lin dan Chen (2017) motivasi dan belajar merupakan dua hal saling mempengaruhi, peserta didik akan giat belajar jika ia mempunyai motivasi untuk belajar. Melihat kenyataan dilapangan bahwa motivasi belajar peserta didik pada mata pelajaran Tematik masih rendah. Keaktifan peserta didik dapat dilihat dari keikutsertaan peserta didik dalam melaksanakan tugas belajarnya, terlibat dalam memecahkan masalah, bertanya kepada peserta didik lain atau guru apabila tidak memahami persoalan yang dihadapi, berusaha mencari berbagai informasi yang diperluakn untuk memecahkan masalah, melatih diri dalam memecahkan masalah atau soal, serta menilai kemampuan diri sendiri dan hasil-hasil yang diperoleh Farhan dan Satianingsih (2021) Dengan demikian model pembelajaran Problem Based Learning diharapkan dapat meningkatkan keaktifan dan motivasi belajar peserta didik.

Berdasarkan latar belakang yang sesuai dengan diatas, maka akan dilaksanaan penelitian yang berjudul "Peningkatan Keaktifan dan Motivasi Belajar Tema 9 Melalui Model Problem Based Learning Pada Peserta Didik Kelas II Semester 2 SDN Dukuh Menanggal I Tahun Pelajaran 2020/2021”.

\section{Metode}

Penelitian ini merupakan penelitian Tindakan kelas. Penelitian dilakukan pada 
waktu kegiatan pembelajaran pada semester genap bulan Maret tahun pelajaran 2020/2021 terhadap seluruh peserta didik kelas II di SDN Dukuh Menanggal I.

Pelaksanaan penelitian tindakan kelas ini meliputi beberapa siklus. Banyaknya siklus yang digunakan tergantung hasil refleksi dari siklus sebelumnya yang berdaur ulang dan berkelanjutan dari siklus pertama ke siklus berikutnya. Setiap siklus meliputi kegiatan perencanaan tindakan (planning), pelaksanaan tindakan (acting), observasi (observing), dan refleksi (reflecting). Setiap siklus dilakukan dengan memberikan tindakan pelatihan dengan penerapan model pembelajaran Problem Based Learning berbasis TPACK dan diakhiri dengan refleksi dan evaluasi pembelajaran.

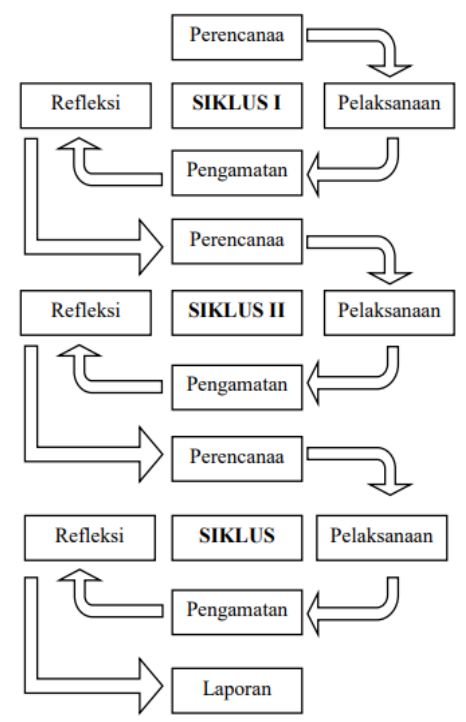

Gambar 1. Prosedur Penelitian

Peneliti menggunakan beberapa metode pengumpulan data, yaitu dokumentasi, observasi, dan angket/kuesioner. Metode observasi digunakan peneliti untuk mengukur peningkatan keaktifan peserta didik setelah diberikan tindakan. Peningkatan keaktifan yang diamati oleh peneliti adalah aktivitas peserta didik dalam mengikuti pembelajaran. Observasi yang dilakukan peneliti menggunakan lembar observasi aktivitas peserta didik dan angket motivasi belajar peserta didik.

Analisis data kualitatif digunakan untuk memaknai atau menafsirkan hasil pengamatan, dalam hal ini dikhususkan pada tindakan yang dilakukan guru selama proses pembelajaran. Hasil refleksi siklus I menjadi dasar untuk pelaksanaan siklus II dan seterusnya. Analisis data kualitatif dalam penelitian ini adalah dengan memaknai dokumentasi yaitu foto yang didapatkan selama proses pembelajaran berlangsung. Analisis data lain yaitu analisis data kuantitatif, analisis data ini digunakan untuk menentukan peningkatan keaktifan dan hasil belajar peserta didik melalui tindakan dari setiap siklus yang dilakukan guru. Tujuan analisis data dalam penelitian tindakan ini adalah untuk memperoleh data apakah terjadi perbaikan dan peningkatan sebagaimana yang diharapkan. Analisis data kuantitatif dalam penelitian ini adalah analisis lembar observasi aktivitas peserta didik. Data yang dianalisis scara kuantitatif berupa angket untuk mengukur keaktifan belajar peserta didik dan lembar observasi keaktifan peserta didik.

\section{Hasil dan Pembahasan}


Penelitian Tindakan kelas ini dilaksanakan di kelas IISDN Dukuh Menanggal I. Penelitian Tindakan Kelas ini dilaksanakan dalam 2 siklus untuk menentukan bagaimana cara meningkatkan keaktifan dan motivasi belajar pada peserta didik dalam proses pembelajaran tema 9. Penelitian dilaksanakan mulai dari pemeriksaan tahap Pra Siklus sampai pada siklus ketiga.

Dari hasil pengamatan dan olah data yang dilakukan peneliti menggunakan lembar observasi keaktifan belajar peserta didik diperoleh data yaitu 8 peserta didik dengan kriteria sangat rendah, 4 peserta didik dengan kriteria keaktifan rendah, 19 peserta didik dengan kriterian keaktifan sedang, dan 4 dengan kriteria keaktifan tinggi. Presentase capaian keaktifan peserta didik dituliskan dalam bentuk diagram berikut.

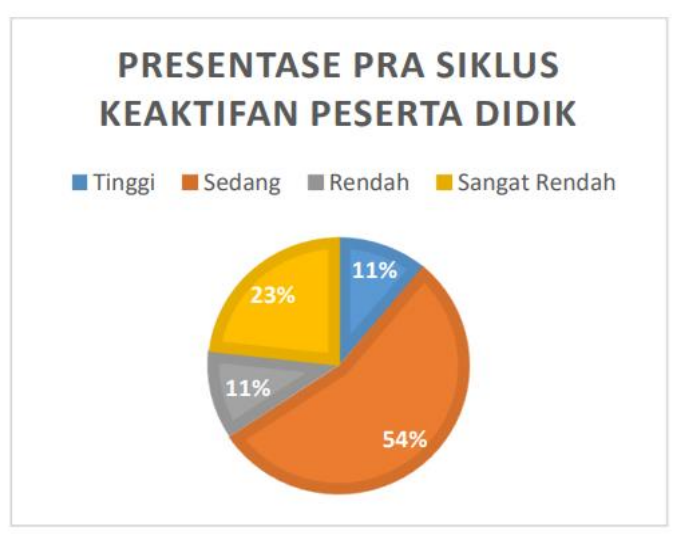

Gambar 2. Presentase Pra Siklus Keaktifan Peserta Didik

Dari hasil pengamatan dan olah data yang dilakukan peneliti menggunakan angket observasi motivasi belajar peserta didik diperoleh data yaitu 15 peserta didik dengan kriteria keaktifan rendah, 9 peserta didik dengan kriterian keaktifan sedang, dan 11 dengan kriteria keaktifan tinggi. Presentase pencapaian motivasi belajar peserta didik dituliskan dalam bentuk diagram berikut.

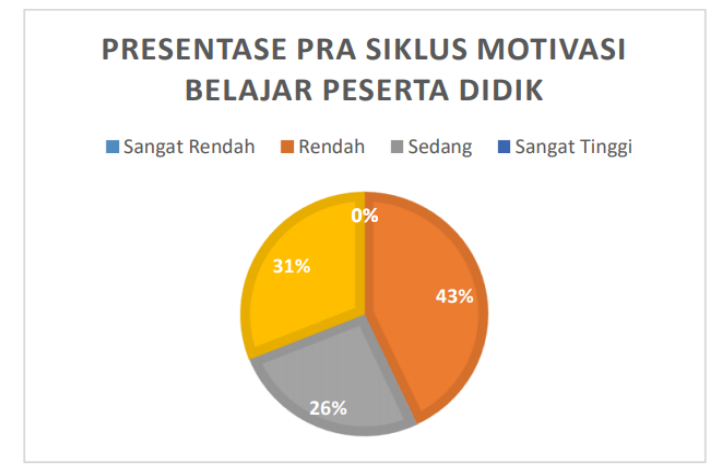

Gambar 3. Presentase Pra Siklus Motivasi Belajar Peserta Didik

Perencanaan Pelaksanaan Tindakan Kelas siklus I mengacu pada hasil observasi prasiklus yang dilaksanakan pada pembelajaran tema 8 . Pada hasil observasi tahap awal permasalahan yang ditemui adalah sebagai berikut: a) Keaktifan peserta didik dalam proses pembelajaran daring masih kurang. Prosentase keaktifan peserta didik dalam pembelajaran Tema 8 yaitu sebesar 23\% pada kriteria sangat rendah, $11 \%$ pada kriteria rendah, $54 \%$ pada kriteria sedang, dan $43 \%$ pada kriteria tinggi dengan rata-rata nilai keaktifan mencapai 53. b) Motivasi belajar peserta didik dalam proses pembelajaran daring masih kurang. Presentase yang didapatkan pada hasil motivasi belajar Tema 8 yaitu kriteria rendah sebesar 43\%, pada 
kriteria sedang terdapat $26 \%$, dan kriteria tinggi terdapat $31 \%$ dengan rata-rata nilai motivasi belajar mencapai 53. c) Saat pembelajaran peserta didik masih cenderung pasif, hanya sebagian saja yang aktif. d) Media ajar pada pembelajaran kurang dimanfaatkan oleh guru. Dari permasalahan yang ada, maka diputuskan untuk melakukan perbaikan pembelajaran untuk meningkatkan keaktifan dan motivasi belajar peserta didik pada pembelajaran tema 9 .

Hasil pengamatan yang dilakukan oleh observer dan peneliti selama pelaksanaan perbaikan pembelajaran melalui penelitian Tindakan kelas dengan model Problem Based Learning pada siklus I terdapat beberapa peserta didik yang pasif dalam proses pembelajaran. Hal tersebut tampak saat proses pembelajaran peserta didik terlihat diam dan tidak merespon untuk menjawab pertanyaan arahan dari guru. Selain itu juga terlihat pada hasil pengumpulan tugas yang dikerjakan peserta didik dimana pada peberapa peserta didik sering kali melewati soal dan tidak sesuai dengan perintah yang diberikan oleh guru.

Pelaksanaan Tindakan Kelas siklus II mengacu pada hasil pembelajaran pertemuan yang dilaksanakan pada siklus 2 dengan 2 pertemuan praktik pembelajaran.

Hasil pengamatan yang dilakukan oleh observer dan peneliti selama pelaksanaan perbaikan pembelajaran melalui penelitian
Tindakan kelas dengan model Problem Based Learning pada siklus II yang sudah ada peningkatan terdapat beberapa siswa yang cukup antusias dalam proses pembelajaran. Hal tersebut tampak saat proses pembelajaran peserta didik banyak yang aktif dan bersemangat saat merespon untuk menjawab pertanyaan arahan dari guru. Selain itu juga terlihat pada hasil pengumpulan tugas yang dikerjakan oleh peserta didik dimana pada beberapa peserta didik mengumpulkan tugas dengan tepat waktu sesuai dengan perintah yang diberikan oleh guru. Hal tersebut disebabkan karena media yang digunakan guru dalam pembelajaran dirasa cukup menarik dan peserta didik lebih termotivasi untuk mengembangkan kemampuanya dalam belajar.

Hasil observasi siklus 2 meliputi pertemuan 1 dan pertemuan 2 diperoleh skor keaktifan berikut.

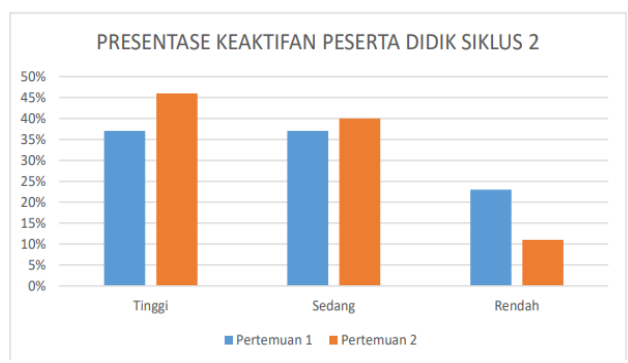

Gambar 4. Presentase Keaktifan Peserta Didik Siklus 2

Berdasarkan tabel diatas dapat dilihat bahwa presentase keaktifan peserta didik sebelum tindakan dan setelah tindakan mengalami kenaikan walaupun belum 
memeuhi kriteria yang ditentukan. Presentase keaktifan belajar peserta didik sebelum melakukan tindakan yaitu sebanyak $37 \%$ dengan kategori tinggi, 37\% dengan kategori sedang, dan $23 \%$ dengan kategori rendah. Sedangkan setelah Tindakan pada siklus II presentase keaktifan peserta didik menunjukan kenaikan yaitu sebesar $46 \%$ pada kategori tinggi, $40 \%$ dengan kategori sedang, dan $11 \%$ dengan kegori rendah. Untuk mencapai hasil pembelajaran yang lebih optimal lagi, peneliti berupaya untuk melakukan evaluasi dan refleksi dari kegiatan pembelajaran pada siklus II.

Dari hasil observasi siklus 2 meliputi pertemuan 1 dan pertemuan 2 diperoleh skor motivasi belajar berikut ini.

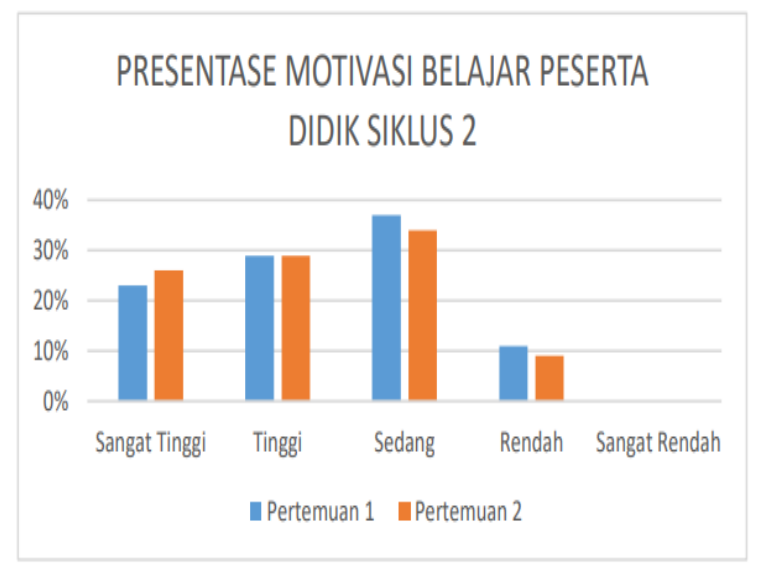

Gambar 5. Presentase Capaian Motivasi Belajar Peserta Didik Siklus 2

Berdasarkan tabel diatas dapat dilihat bahwa presentase motivasi belajar peserta didik sebelum tindakan dan setelah tindakan mengalami kenaikan walaupun belum memeuhi kriteria yang ditentukan. Presentase motivasi belajar peserta didik sebelum melakukan tindakan yaitu sebanyak 23\% dengan kategori sangat tinggi, 29\% dengan kategori tinggi, 37\% dengan kategori sedang, $11 \%$ dengan kategori rendah, dan $0 \%$ dengan kategori sangat rendah. Sedangkan setelah Tindakan pada siklus II presentase motivasi belajar peserta didik menunjukan kenaikan yaitu sebesar 26\% dengan kategori sangat tinggi, 29\% pada kategori tinggi, 34\% dengan kategori sedang, dan 9\% dengan kegori rendah, dan $0 \%$ untuk kategori sangat rendah. Untuk mencapai hasil pembelajaran yang lebih maksimal lagi, peneliti berupaya untuk melakukan evaluasi dan melakukan refleksi dari kegiatan pembelajaran pada siklus II.

\section{Kesimpulan}

Berdasarkan hasil penelitian yang telah dilakukan dapat disimpulkan bahwa model pembelajaran Problem Based Learning terbukti dapat meningkatkan keaktifan dan motivasi belajar peserta didik terhadap materi Tema 9 dengan melakukan praktik pembelajaran 6 kali pertemuan pada 2 siklus yang dilaksanakan oleh peserta didik kelas II SDN Dukuh Menanggal I. Hal ini didukung oleh data-data berikut yang dilihat dari: (1) Keaktifan belajar peserta didik pada prasiklus hasil rata-rata nilai keaktifan pada peserta didik yaitu 53. Kemudian Siklus 1 didapatkan rata-rata nilai keaktifan peserta didik mencapai 57. Tahap Siklus 2 mengalami peningkatan 
dengan perolehan nilai rata-rata keaktifan peserta didik mencapai 71 .

\section{Daftar Pustaka}

Amir, M. F. (2018). Pengembangan perangkat pembelajaran berbasis masalah kontekstual untuk meningkatkan kemampuan metakognisi siswa sekolah dasar. Journal of Medives: Journal of Mathematics Education IKIP Veteran Semarang, 2(1), 117-128.

Fanny, A. M. (2019, March). Analysis Of Pedagogical Skills And Readiness Of Elementary School Teachers In Support Of The Implementation Of The 2013 Curriculum. In International Conference on Bussiness Law and Pedagogy (Vol. 1, No. 1, pp. 59-63).

Farhan, M., \& Satianingsih, R. (2021). Problem Based Learning On Literacy Mathematics: Experimental Study in Elementary School. Journal of Medives: Journal of Mathematics Education IKIP Veteran Semarang, 5(1), 118-128.
Jamal, S. N. B., Ibrahim, N. H. B., \& Surif, J. B. (2019). Concept cartoon in problembased learning: A systematic literature review analysis. JOTSE: Journal of Technology and Science Education, 9(1), 51-58.

Lin, M. H., \& Chen, H. G. (2017). A study of the effects of digital learning on learning motivation and learning outcome. Eurasia Journal of Mathematics, Science and Technology Education, 13(7), 3553-3564.

Mann, L., Chang, R., Chandrasekaran, S., Coddington, A., Daniel, S., Cook, E., ... \& Smith, T. D. (2021). From problembased learning to practice-based education: A framework for shaping future engineers. European Journal of Engineering Education, 46(1), 27-47.

Sari, P. M., \& Sulistyawati, I. (2021). Students' Critical Thinking Ability on Solving 6th Grade Mathematical Problems at SD Hang Tuah 10 Juanda. Journal of Medives: Journal of Mathematics Education IKIP Veteran Semarang, 5(2), 223-233. 